\section{Managing Fruit Soluble Solids with Late-season Deficit Irrigation in Drip-irrigated Processing Tomato Production}

\author{
P.R. Johnstone, T.K. Hartz, M. LeStrange, ${ }^{1}$ J.J. Nunez, ${ }^{1}$ and \\ E.M. Miyao ${ }^{1}$ \\ Department of Plant Sciences, University of California, Davis, CA 95616
}

Additional index words. Lycopersicon esculentum, fruit quality, brix monitoring, brix yield

\begin{abstract}
Fruit soluble solids concentration (SSC) is an important quality factor for tomatoes (Lycopersicon esculentum Mill.) grown for processing. The use of drip irrigation often results in undesirably low SSC. The effects of late-season irrigation management on fruit yield and SSC was investigated in a series of drip-irrigated field trials in California from 2000-04. The effects of irrigation cutoff or deficit irrigation implemented 40 to 50 days preharvest (the period corresponding to the initiation of fruit ripening) were compared to a standard grower practice of irrigation cutoff $\mathbf{2 0}$ days preharvest. Irrigation cutoff 40 to 50 days preharvest increased SSC but resulted in substantial yield loss, with significantly reduced brix yield (Mg fruit solids $\mathrm{ha}^{-1}$ ). By contrast, deficit irrigation significantly increased SSC compared to the standard practice, with no significant loss of brix yield. In three commercial fields the effect of deficit irrigation on fruit SSC was investigated. Fruits were sampled on three dates: 1) 4 to 5 weeks preharvest, early-ripening, pink-stage fruit only, 2) about 1 week preharvest, both late-ripening, pink-stage fruit and early-ripening fruit now fully ripe, and 3) commercial harvest, composite of early- and late-maturing fruit. SSC increased in response to soil moisture stress induced by deficit irrigation, with late-maturing fruit as much as $1.6^{\circ} \mathrm{brix}$ higher than fruit maturing before significant soil moisture stress. However, once a fruit reached the pink stage of maturity, its SSC was not affected by subsequent soil moisture stress. An additional five commercial field trials were conducted to compare growers' irrigation practices with greater degrees of deficit irrigation. In each field the grower's deficit irrigation regime was compared to a reduced treatment receiving $25 \%$ to $50 \%$ less water over the final 4 to 7 weeks before harvest. Across fields, applying $20 \%$ to $60 \%$ of reference evapotranspiration (ET) over the fruit ripening period resulted in acceptable SSC without significant brix yield reduction. We conclude that deficit irrigation initiated during early fruit ripening provides a flexible tool for SSC management. Brix monitoring of earliest ripening fruit can help classify fields as to the severity of irrigation deficit required to reach desirable SSC at harvest.
\end{abstract}

The use of drip irrigation in California processing tomato production is increasing rapidly, with $>12,000$ ha drip-irrigated in 2004 . Drip irrigation minimizes plant water stress during growth and development by allowing frequent, small-volume irrigations (Hartz, 1996), and offers the potential to efficiently deliver nutrients (Hartz and Hochmuth, 1996). Conversion to drip irrigation has typically increased processing tomato fruit yield by $20 \%$ or more compared to furrow irrigation, the industry standard. However, some processors remain skeptical of drip irrigation because fruit soluble solids concentration (SSC) has generally been lower than that achieved with furrow irrigation; high SSC improves both paste yield per unit of fresh fruit and overall processing efficiency. Linden (2004) reported that each $0.1^{\circ}$ brix decrease in SSC costs California processors about $\$ 1.30 / \mathrm{Mg}$ of raw product in additional processing and handling.

Drip irrigation management affects both tomato yield and SSC (Cahn et al., 2001, 2003;

Received for publication 18 Apr. 2005. Accepted for publication 18 June 2005 .

${ }^{1}$ University of California Cooperative Extension.
Dumas et al., 1994; Lowengart-Aycicegi et al., 1999; May and Gonzales, 1999). All reported that imposing soil moisture stress during fruit sizing and ripening reduced yield while increasing SSC. A common management approach to increasing fruit SSC in drip-irrigated fields has been full irrigation cutoff implemented during the fruit ripening period. With the determinate cultivars currently used, fruit ripening typically encompasses the final 6 weeks before harvest. Irrigation cutoff 6 weeks or more preharvest can dramatically reduce fruit set, decrease fruit size, and substantially increase the incidence of fruit
${ }^{\mathrm{z} U C D}=$ University of California-Davis. rots, making this approach uneconomical (May and Gonzales, 1999). Irrigation cutoffs within the final 6 weeks have given highly variable results, in some fields having no impact on SSC, while in others causing an unacceptable degree of yield loss. This variability appeared largely related to field-specific factors (soil texture, rooting depth, wetting pattern from the drip tape, etc.), making it impossible to develop a generic cutoff date recommendation. Currently, many California growers adopt a conservative approach of full irrigation until cutoff 10 to $20 \mathrm{~d}$ preharvest.

An alternative approach to complete irrigation cutoff is deficit irrigation. Imposing a controlled water deficit early in the fruit ripening phase has shown the potential to increase SSC with only a minimal sacrifice in fruit yield (Cahn et al., 2001; Renquist and Reid, 2001). The objective of this research was to evaluate the effects of late-season deficit irrigation management on fruit yield and SSC of drip-irrigated processing tomatoes across a range of field conditions representative of the California industry.

\section{Materials and Methods}

University of California-Davis (UCD) trials, 2000-02. One irrigation trial per year was conducted in drip-irrigated fields at UCD from 2000-02 to compare the effect of irrigation cutoffand deficit irrigation on tomato fruit yield and SSC. Soil characteristics and production practices were similar in all years (Table 1). The soil was Yolo loam $(2000,2002)$ or Reiff $\operatorname{loam}(2001)$; both soils were mixed, non-acid, thermic Typic Xerorthents. Transplants of 'Halley' were grown in single rows on $1.5-\mathrm{m}$ wide raised soil beds and irrigated with one drip line buried $20 \mathrm{~cm}$ deep in the center of each bed. Fertility and pest management practices followed standard commercial procedures. No precipitation was received between the initiation of the irrigation treatments and harvest in any season.

In each trial, irrigation was applied 3 times per week, with the volume recorded by water meters. All plots received full irrigation until 6 to 7 weeks preharvest (corresponding to approximately the onset of fruit ripening). Full irrigation was defined as ET $\times$ crop coefficient $(\%$ canopy cover $\times 1.1) \times 1.15$ (system inefficiency factor).

Daily reference evapotranspiration (ET) was estimated from the nearest computerized weather station of the California Irrigation Table 1. Location, soil texture, cultivar, and harvest date for drip-irrigated trial fields (2000-04).

\begin{tabular}{lcccc}
\hline Year & Location & Soil texture & Cultivar & Harvest date \\
\hline 2000 & UCD $^{z}$ & Loam & Halley & 29 Aug. 2000 \\
2001 & UCD & Loam & Halley & 21 Aug. 2001 \\
2002 & UCD & Loam & Halley & 28 Aug. 2002 \\
2003 & Kern & Silty clay loam & Heinz 9494 & 8 Aug. 2003 \\
& Fresno & Sandy loam & Hypeel 303 & 2 Sept. 2003 \\
& Yolo & Clay loam & HM 830 & 8 Sep. 2003 \\
2004 & Five Points & Sandy clay loam & AB2 & 19 July 2004 \\
& Cantua Creek & Sandy clay loam & AB2 & 23 July 2004 \\
& Mendota & Clay & Peto 849 & 17 Aug. 2004 \\
& Firebaugh & Clay & Heinz 9665 & 14 Sept. 2004 \\
& Coalinga & Clay & Heinz 9663 & 21 Sept. 2004 \\
\hline
\end{tabular}


Management Information System (CIMIS) network $(<1 \mathrm{~km}$ from the UCD experimental sites); ET o was calculated using a modifiedPenman equation and hourly weather data (Goldhamer and Snyder, 1989). The standard irrigation treatment, representing a common commercial practice, continued to receive full irrigation until cutoff $20 \mathrm{~d}$ preharvest. An early irrigation cutoff treatment was implemented by terminating irrigation either $40 \mathrm{~d}(2000,2001)$ or $50 \mathrm{~d}$ (2002) preharvest. Concurrent with the establishment of the early cutoff treatment, a deficit irrigation treatment was also initiated in which $25 \%$ of full irrigation was delivered until $20 \mathrm{~d}$ preharvest, at which time irrigation ceased. The experimental design in each season was a randomized, complete block with either five $(2000,2001)$ or six (2002) replications. Individual plots were one bed wide $\times 15 \mathrm{~m}$ long. At commercial maturity ( $>95 \%$ ripe fruit) a 5$\mathrm{m}$-long section of each plot was hand harvested. Fruit were graded into marketable (colored or red fruit that were free of major defects), green and cull categories. A 5-kg subsample of marketable fruit per plot was mechanically juiced and deaerated under a vacuum of $0.09 \mathrm{MPa}$. SSC ( ${ }^{\circ}$ brix) was determined by refractometer and blended color quantified as the ratio of green $(566 \mathrm{~nm})$ to red $(650 \mathrm{~nm})$ light reflected from the homogenized juice sample. Fruit $\mathrm{pH}$ was determined using a $\mathrm{pH}$ meter.

Commercial trials, 2003-04. Three trials were conducted in commercial processing tomato fields in Kern, Fresno, and Yolo Counties in 2003 to further investigate the relationships between grower-imposed soil moisture stress and fruit maturation and SSC; there were no comparison cutback treatments in these trials. These fields represented different growers, and a range of soil conditions and cultivars (Table 1). All fields were drip-irrigated, with one drip line buried 25 to $30 \mathrm{~cm}$ deep in the center of each raised soil bed. Reference ET for each experimental sites was determined from the closest CIMIS station, which was within $15 \mathrm{~km}$ for all fields. The cooperating growers all practiced deficit irrigation, applying $83 \%, 55 \%$, and $77 \%$ of $\mathrm{ET}_{\mathrm{o}}$ respectively, over the final 6 weeks of the season. Crop ET over this period would be about $80 \%$ to $90 \%$ of $\mathrm{ET}_{\mathrm{o}}$ (Phene et al., 1986). Before the imposition of these deficits, all fields had been fully watered to minimize stress during fruit set. Water meters were installed in the drip lines of five (Kern) or six (Fresno and Yolo) individual beds, about $120 \mathrm{~m}$ from the tail end of the field. Electrical resistance sensors (Watermark blocks, Irrometer Co., Riverside, Calif.) were installed 40 and 80 $\mathrm{cm}$ deep in plant rows, three replications per depth per field. Resistance readings were recorded every $6 \mathrm{~h}$ by datalogger (model 21X; Campbell Scientific, Logan, Utah) and converted to $\mathrm{kPa}$ tension by the method of Shock et al. (1998). About 4 to 5 weeks before anticipated harvest, 15 to 20 fruit at the pink stage of ripeness $(30 \%$ to $60 \%$ of the surface showing color other than green; USDA, 1991) were harvested from each test row for SSC determination. An additional set of pink-stage fruit were marked with an indelible marker and left on the vine to ripen; these marked fruit were picked about 1 week before commercial harvest ( 3 to 4 weeks after being marked) and evaluated for SSC to determine whether deficit irrigation affected fruit that had already reached the pink stage of maturity. Concurrent with the harvest of the marked fruit, matching samples of latematuring fruit just reaching the pink-stage of ripeness were also collected and analyzed for SSC. Lastly, at commercial maturity a $5-\mathrm{kg}$ composite sample per test row containing both early- and late-ripening fruit were harvested for SSC determination.

Based on the results of the 2000-03 studies, a final series of five commercial field trials were conducted in Fresno County in 2004 to quantify the effect of deficit irrigation on tomato fruit yield and SSC. These fields represented different growers, soil conditions and cultivars, and a harvest period from 19 July to 21 Sept. (Table 1). All fields were drip-irrigated, with one drip line buried 25 to $35 \mathrm{~cm}$ deep in the center of raised soil beds. Reference ET for each experimental site was determined from the closest CIMIS station, which was within $12 \mathrm{~km}$ for all fields. At the initiation of fruit ripening, water meters were installed in the drip lines of seven individual beds in each field, 120 $\mathrm{m}$ from the tail end of the field. Two of these water meters documented the growers' irrigation treatment. On the remaining five water meters a restrictor valve was attached. Prior to fruit ripening all fields were fully watered to minimize stress during fruit set; during the fruit ripening period the growers imposed varying degrees of irrigation deficit. Between 4 to 7 weeks preharvest (corresponding to about 5\% to $25 \%$ of fruit showing external color change) the valves were partially closed, reducing irrigation flow in these drip lines by $25 \%$ to $50 \%$. Fruit yield and SSC from the rows receiving reduced irrigation were compared with that of matching rows receiving the growers' irrigation treatment. The experimental design at all sites was a randomized complete block, with five replications. No precipitation was received at any site between the initiation of the reduced irrigation treatment and harvest.

On the day the reduced irrigation treatment began, about 20 fruit per block at the pinkstage of ripeness were collected, juiced, and evaluated for SSC. A sample of later-maturing pink-stage fruit from each of the grower irrigation rows was harvested 2 to 4 weeks later. Immediately prior to commercial harvest, two 5-m-long sections from each plot were hand harvested. Fruit were graded into marketable, green, and cull categories, and total and marketable yields were calculated. Fruit SSC, color and $\mathrm{pH}$ were determined from blended samples of $5 \mathrm{~kg}$ of marketable fruit per plot.

Effect of preharvest irrigation. Additional trials were conducted at UCD, two in 2003 and

Table 2. Effect of irrigation cutoff and deficit irrigation on tomato yield and fruit quality, 2000-02 UCD trials.

\begin{tabular}{|c|c|c|c|c|c|c|c|c|}
\hline \multirow[b]{2}{*}{ Year } & \multirow{2}{*}{$\begin{array}{l}\text { Irrigation } \\
\text { treatment }^{\mathrm{y}}\end{array}$} & \multirow{2}{*}{$\begin{array}{l}\text { Treatment initiation } \\
\text { (days preharvest) }\end{array}$} & \multicolumn{2}{|c|}{$\begin{array}{l}\qquad \mathrm{ET}_{\mathrm{o}}^{\mathrm{z}} \text { over } \\
\text { treatment period }\end{array}$} & \multicolumn{2}{|c|}{$\begin{array}{c}\text { Fruit yield } \\
\left(\mathrm{Mg} \cdot \mathrm{ha}^{-1}\right) \\
\end{array}$} & \multirow{2}{*}{$\begin{array}{l}\text { Soluble } \\
\text { solids } \\
\text { ( }{ }^{\circ} \text { brix) }\end{array}$} & \multirow{2}{*}{$\begin{array}{c}\text { Brix } \\
\text { yield } \\
\left(\mathrm{Mg} \cdot \mathrm{ha}^{-1}\right)\end{array}$} \\
\hline & & & $\overline{(\mathrm{mm})}$ & $\overline{(\% \text { applied })}$ & Total & $\overline{\text { Marketable }}$ & & \\
\hline \multirow[t]{4}{*}{2000} & Standard & 20 & 252 & 56 & 83 & 74 & 5.33 & 3.96 \\
\hline & Cutoff & 40 & & 0 & 78 & 70 & 5.55 & 3.85 \\
\hline & Deficit & 40 & & 14 & 86 & 77 & 5.48 & 4.20 \\
\hline & & & & & NS & NS & NS & NS \\
\hline \multirow[t]{4}{*}{2001} & Standard & 20 & 267 & 64 & 98 & 91 & $5.52 \mathrm{~b}^{\mathrm{x}}$ & 5.02 \\
\hline & Cutoff & 40 & & 0 & 88 & 81 & $5.88 \mathrm{a}$ & 4.74 \\
\hline & Deficit & 40 & & 16 & 97 & 92 & $5.60 \mathrm{~b}$ & 5.15 \\
\hline & & & & & $*$ & $*$ & $* *$ & NS \\
\hline \multirow[t]{4}{*}{2002} & Standard & 20 & 324 & 77 & $125 \mathrm{a}$ & $109 \mathrm{a}$ & $5.28 \mathrm{~b}$ & 5.74 \\
\hline & Cutoff & 50 & & 0 & $103 \mathrm{~b}$ & $88 \mathrm{~b}$ & $5.90 \mathrm{a}$ & 5.19 \\
\hline & Deficit & 50 & & 19 & $117 \mathrm{a}$ & $106 \mathrm{a}$ & $5.52 \mathrm{ab}$ & 5.83 \\
\hline & & & & & $* *$ & $* *$ & $* *$ & NS \\
\hline \multirow{4}{*}{$\begin{array}{l}\text { Year } \times \text { treatment } \\
\text { Average }\end{array}$} & & & & & NS & NS & NS & NS \\
\hline & Standard & & & 66 & $102 \mathrm{a}$ & $91 \mathrm{a}$ & $5.38 \mathrm{c}$ & $4.91 \mathrm{a}$ \\
\hline & Cutoff & & & 0 & $90 \mathrm{~b}$ & $79 \mathrm{~b}$ & $5.78 \mathrm{a}$ & $4.59 \mathrm{~b}$ \\
\hline & Deficit & & & 16 & $\begin{array}{c}100 \mathrm{a} \\
* *\end{array}$ & $\begin{array}{c}92 \mathrm{a} \\
* *\end{array}$ & $\begin{array}{c}5.53 \mathrm{~b} \\
* *\end{array}$ & $\begin{array}{c}5.06 \mathrm{a} \\
* *\end{array}$ \\
\hline
\end{tabular}

${ }^{\mathrm{z}} \mathrm{ET}=$ reference evapotranspiration.

${ }^{y}$ Standard treatment applied full irrigation until complete cutoff 3 weeks preharvest; irrigation cutoff and deficit irrigation (25 \% of full) initiated on designated day.

${ }^{x}$ Means within columns separated using Duncan's multiple range test, $p<0.05$.

NS, ${ }^{*, * *}$ Nonsignificant or significant at $p<0.10$ or 0.05 , respectively. 

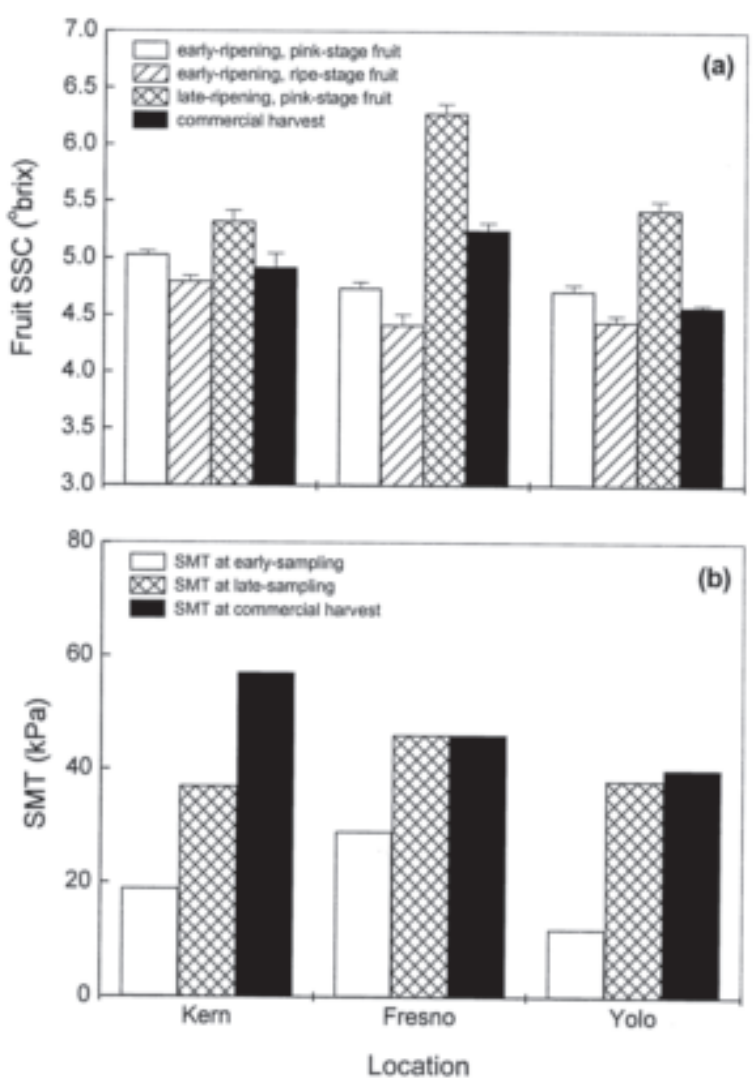

Fig. 1. Effect of deficit irrigation on (a) fruit soluble solids concentration (SSC) and (b) soil moisture tension (SMT, mean of 40 to $80 \mathrm{~cm}$ depth), 2003 trials. Fruits sampled on three dates: 1 ) early ( 4 to 5 weeks preharvest), early-ripening, pink-stage fruit only; 2) late (1 week preharvest), both late-ripening, pink-stage fruit and early-ripening fruit now fully ripe; and 3) commercial harvest, composite of early-and late-ripening fruit. Bars indicate standard error.

analyzed for SSC to assess the effect of the applied water.

All statistical analyses were performed using the GLMANOVA procedure within SAS software (SAS Institute Inc. Cary, N.C.).

\section{Results}

In the 2000-02 UCD trials fruit yield achieved with the standard irrigation treatment varied considerably among years (Table 2). Acceptable fruit SSC values ( $>5.0^{\circ}$ brix) were achieved in all seasons. Brix yield (marketable yield $\times$ SSC) averaged $4.9 \mathrm{Mg}$ fruit solids/ha. Although irriga-

one in 2004, to determine whether watering at commercial maturity affected SSC of fruit that were already ripe. All fields were managed using standard production techniques, involving full irrigation until cutoff 3 weeks preharvest. At commercial maturity, a 5-kg sample of ripe (fully-red) fruit was collected from each of five rows per field and SSC determined. Irrigation of 30,50 , or $100 \mathrm{~mm}$ was subsequently applied in fields 1,2 , and 3, respectively. These irrigations were by buried drip (field 1 and 3 ) or conventional surface furrow (field 2). Two days after this irrigation a second set of ripe fruit samples from the same rows were collected and percent culls (8\% for the early cutoff and 5\% for the standard and deficit treatments; data not shown).

In the 2003 commercial fields, SSC of early-ripening pink fruit varied among fields from 4.7 to $5.0^{\circ}$ brix (Fig. 1a). SSC of lateripening pink fruit was significantly higher than that of early-ripening fruit, apparently affected by soil moisture stress induced by deficit irrigation in the final weeks. In all fields soil moisture tension across the 40 to $80 \mathrm{~cm}$ depth rose substantially over the fruit sampling period (Fig. 1b). However, SSC of the marked, early-ripening fruit declined over this same time period by an average of 0.2 to $0.3^{\circ}$ brix in all fields, despite having been exposed to the same moisture stress as the late-ripening fruit. This implied that, once the pink-stage of ripeness was reached (and perhaps earlier), fruit SSC was no longer affected by soil moisture stress. The SSC decline of early-ripening fruit between the pink and mature red stages of development was presumably due to respiratory metabolism.

Based on the assumption that crop ET over the final 4 to 6 weeks of the season would have been about $80 \%$ to $90 \%$ of ET (Phene et al., 1986), all 2004 commercial fields received deficit irrigation, varying in the degree of severity (Table 3). The SSC of early-ripening pink fruit collected 4 to 5 weeks preharvest varied among fields from 4.2 to $5.4^{\circ}$ brix (Fig. 2). This range was undoubtedly attributable both to innate cultivar characteristics as well as field-specific soil and management factors. Later-ripening fruit exposed to the growers' deficit irrigation while still green had substantially higher SSC than early-ripening fruit; across fields this difference averaged about $0.8^{\circ}$ brix. In all fields, SSC of composite fruit samples collected at harvest were intermediate between that of early- and late-ripening fruit.

High yield was observed in all fields (Table 3). In four fields high SSC was also achieved, with the grower irrigation treatment averaging $5.3^{\circ}$ brix or higher. At the Coalinga site, SSC

Table 3. Effect of late-season drip irrigation management on tomato yield and fruit quality, 2004 commercial trials.

\begin{tabular}{|c|c|c|c|c|c|c|c|c|}
\hline \multirow[b]{2}{*}{ Year } & \multirow{2}{*}{$\begin{array}{l}\text { Irrigation } \\
\text { treatment }^{y}\end{array}$} & \multirow{2}{*}{$\begin{array}{l}\text { Deficit irrigation } \\
\text { (days preharvest) }\end{array}$} & \multicolumn{2}{|c|}{$\begin{array}{c}\mathrm{ET}_{\mathrm{o}}^{\mathrm{z}} \text { over } \\
\text { treatment period }\end{array}$} & \multicolumn{2}{|c|}{$\begin{array}{l}\text { Fruit yield } \\
\left(\mathrm{Mg} \cdot \mathrm{ha}^{-1}\right)\end{array}$} & \multirow{2}{*}{$\begin{array}{l}\text { Soluble } \\
\text { solids } \\
\text { ('brix) }\end{array}$} & \multirow{2}{*}{$\begin{array}{c}\text { Brix } \\
\text { yield } \\
\left(\mathrm{Mg} \cdot \mathrm{ha}^{-1}\right)\end{array}$} \\
\hline & & & $(\mathrm{mm})$ & (\% applied) & Total & Marketable & & \\
\hline \multirow[t]{3}{*}{ Five Points } & Grower & & 264 & 66 & 172 & 158 & 5.80 & 9.16 \\
\hline & Reduced & 38 & & 46 & 167 & 155 & 6.04 & 9.38 \\
\hline & & & & & NS & NS & $* *$ & NS \\
\hline \multirow[t]{3}{*}{ Cantua Creek } & Grower & & 197 & 57 & 210 & 194 & 5.34 & 10.36 \\
\hline & Reduced & 26 & & 33 & 199 & 187 & 5.42 & 10.14 \\
\hline & & & & & $*$ & NS & NS & NS \\
\hline \multirow[t]{3}{*}{ Mendota } & Grower & & 257 & 32 & 108 & 101 & 5.71 & 5.75 \\
\hline & Reduced & 39 & & 20 & 107 & 102 & 5.69 & 5.79 \\
\hline & & & & & NS & NS & NS & NS \\
\hline \multirow[t]{3}{*}{ Firebaugh } & Grower & & 251 & 67 & 110 & 102 & 5.69 & 5.83 \\
\hline & Reduced & 42 & & 33 & 101 & 94 & 5.93 & 5.59 \\
\hline & & & & & $*$ & $* *$ & $* *$ & NS \\
\hline \multirow[t]{3}{*}{ Coalinga } & Grower & & 295 & 43 & 135 & 123 & 4.74 & 5.81 \\
\hline & Reduced & 46 & & 27 & 130 & 118 & 4.79 & 5.64 \\
\hline & & & & & NS & NS & NS & NS \\
\hline \multirow{4}{*}{$\begin{array}{c}\text { Trial } \times \text { treatment } \\
\text { Average }\end{array}$} & & & & & NS & NS & NS & NS \\
\hline & Grower & & & 53 & 147 & 136 & 5.45 & 7.38 \\
\hline & Reduced & & & 32 & 141 & 131 & 5.60 & 7.31 \\
\hline & & & & & $* *$ & $*$ & $* *$ & NS \\
\hline
\end{tabular}

${ }^{\mathrm{z} E T}=$ reference evapotranspiration.

$\mathrm{NS},{ }^{*, * *}$ Nonsignificant or significant at $p<0.10$ or 0.05 , respectively. 
was comparatively low, although consistent with the low SSC measured in early-ripening fruit. Although the trends were generally not significant for individual fields, across fields the reduced irrigation treatment decreased fruit yield while increasing fruit SSC; overall, brix yield was equivalent in both the grower and reduced irrigation treatments. Differences between irrigation treatments in cull rates, fruit $\mathrm{pH}$ and blended fruit color were not significant, although there was a small but significant difference in percent green fruit (an average of $6 \%$ for grower irrigation and $4 \%$ for reduced

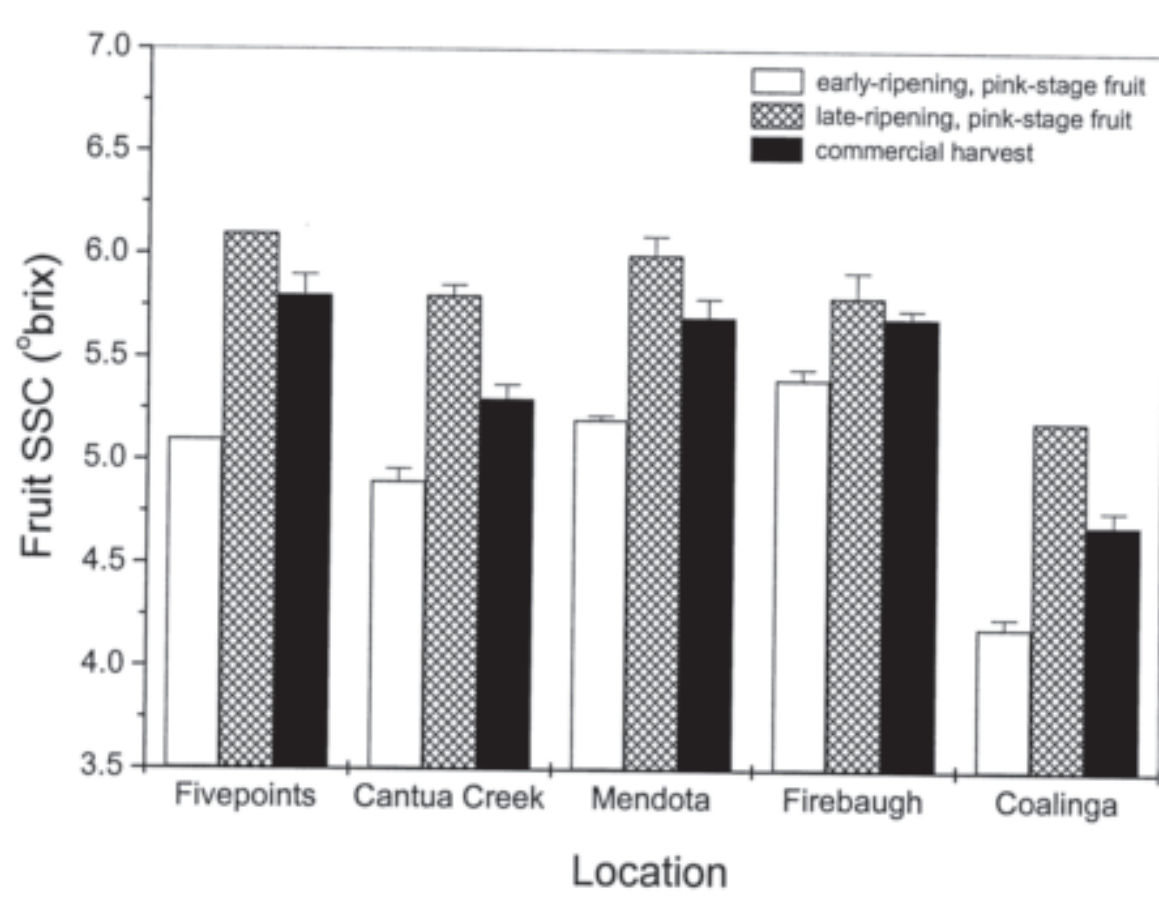

Fig. 2. Effect of the grower deficit irrigation treatment on fruit soluble solids concentration (SSC), 2004 trials. Fruits sampled on three dates: 1 ) early ( 4 to 7 weeks preharvest), early-ripening, pink-stage fruit; 2) late (1 to 3 weeks preharvest), late-ripening, pink-stage fruit; and 3) commercial harvest, composite of early- and late-ripening fruit. Bars indicate standard error.

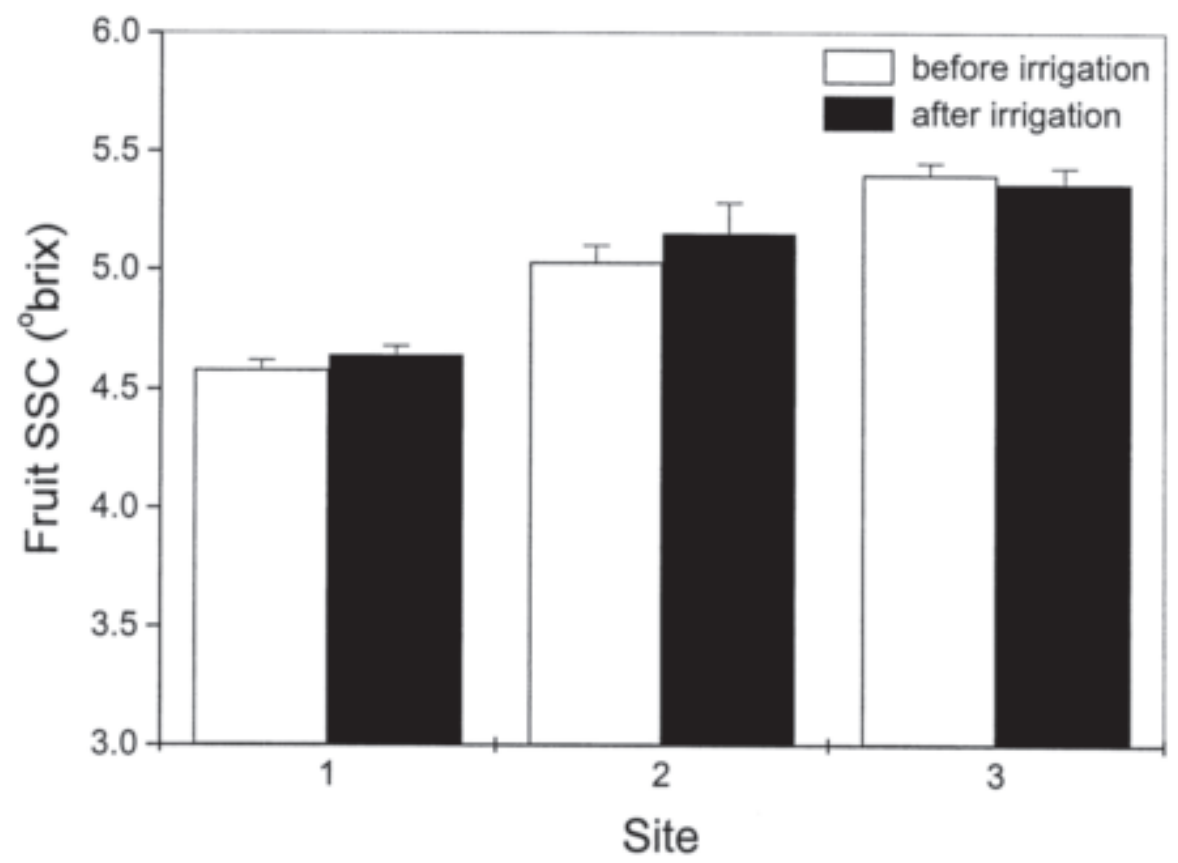

Fig. 3. Effect of preharvest irrigation on soluble solids concentration (SSC) of red fruit, 2003-04 University of California-Davis trials; bars indicate standard error.

\section{Discussion}

Tomatoes with high SSC improve processing efficiency. There is a negative correlation between SSC and fresh fruit yield (Dumas et al., 1994). The goal of late-season irrigation management is to achieve acceptable SSC with the minimal sacrifice of fresh fruit yield (i.e., no reduction of brix yield). Results of the UCD trials confirmed that irrigation cutoff at the onset of fruit ripening was an inappropriate strategy in drip-irrigated fields because although SSC was consistently improved, the large fruit yield reduction resulted in an overall loss of brix yield. Conversely, deficit irrigation initiated at the onset of fruit ripening was consistently effective in increasing SSC without reducing brix yield. This result was consistent with the findings of Cahn et al. (2001).

The apparent superiority of the deficit irrigation approach can be explained by the differing response of green and ripe fruit to soil moisture stress. Soil moisture stress significantly increased SSC of green fruit, but once a fruit reached the pink-stage of maturity subsequent moisture stress had no effect. Analogously, Sakamoto et al. (1999) found that increasing the salinity of a glasshouse nutrient solution at the immature green stage of fruit development increased SSC more than increasing salinity at the decolouring stage. The SSC improvement resulted from a reduction of water import to the fruit, the same mechanism as with water stress (Ehret and Ho, 1986).

Under typical California field conditions, processing tomato fruit ripen over about 6 weeks, at an average rate of $2 \%$ to $3 \%$ of fruit reaching the pink stage of ripeness each day. To significantly influence overall crop SSC, soil moisture stress would need to be imposed while a substantial portion of the crop was still green. An irrigation cutoff imposed 3 weeks preharvest may not result in appreciable SSC improvement because only a minority of fruit will be positively affected. Alternatively, a cutoff 6 weeks preharvest, early enough to cause a stress-induced SSC increase, may result in vine decline and large yield loss. However, deficit irrigation can be initiated early enough to affect the majority of fruit, yet maintain soil moisture at a level sufficient to prevent serious vine decline. Soil moisture monitoring in the 2003 commercial trials showed that substantial fruit SSC increase occurred with only modest soil moisture stress.

The different response of green and ripe fruit to soil moisture stress may also help account for the historical disparity in SSC observed between drip- and furrow-irrigated fields; SSC has typically been 0.2 to $0.5^{\circ}$ brix lower with drip (Hartz, 2001). Furrow irrigation is usually applied at 7 to $14 \mathrm{~d}$ intervals (Hartz and Miyao, 1997), with significant soil drying occurring between irrigations. During a drying cycle the SSC content of green fruit would be increased, and before the next irrigation some of those fruit would mature to the point where the subsequent irrigation would have no effect. By contrast, frequent drip irrigation minimizes soil moisture fluctuation, limiting stress-induced SSC increase. 
The preharvest watering trials, in which even heavy irrigation (up to $100 \mathrm{~mm}$ ) at commercial maturity $(>95 \%$ red fruit) had no effect on SSC of red fruit, confirmed that red fruit SSC can be neither increased nor decreased by soil moisture manipulation. This suggested that irrigation can continue until harvest if desired, provided that water management during fruit ripening is appropriate, and excessive soil moisture does not induce fruit rot or complicate mechanical harvesting. This is an important finding, in that fields that cannot be harvested at ideal maturity can be field-stored, with continued irrigation to maintain vine vigor. We did not evaluate the effect of rainfall on ripe fruit $\mathrm{SSC}$; it is possible that water may be absorbed directly into fruit, lowering SSC.

Studies presented here indicated that dripirrigated processing tomatoes can tolerate a significant degree of water stress before brix yield is compromised. Across a range of field conditions, deficit irrigation regimes as low as $20 \%$ to $40 \%$ of ET over the fruitripening period did not reduce brix yield when compared to substantially wetter treatments. Growers appear to have considerable flexibility in late-season drip irrigation scheduling, enabling them to tailor irrigation to account for field-specific factors such as SSC of early-ripening fruit. The consistent pattern of fruit SSC development in response to deficit irrigation suggested that SSC monitoring of pink-stage fruit could be a useful tool in irrigation scheduling. The large difference among fields in SSC of early-ripening fruit (4.2 to $5.4^{\circ}$ brix in the 2004 trials) emphasized that some fields may require more severe irrigation deficit to achieve acceptable fruit SSC than others.

In summary, initiating deficit irrigation early in the fruit ripening period, and applying $20 \%$ to $60 \%$ of $\mathrm{ET}_{\text {。 }}$ from then until harvest, achieved acceptable fruit SSC with no loss of brix yield across a range of field conditions. In addition to using crop ET scheduling, monitoring the brix of pink-stage fruit can aid a grower in adjusting a deficit irrigation regime to fit field-specific conditions.

\section{Literature Cited}

Cahn, M.D., E.V. Herrero, B.R. Hanson, R.L. Snyder, T.K. Hartz, and E.M. Miyao. 2003. Effects of irrigation cutoff on processing tomato fruit quality. Acta Hort. 613:75-80.

Cahn, M.D., E.V. Herrero, B.R. Hanson, T.K. Hartz, and E.M. Miyao. 2001. Water management strategies for improving fruit quality of drip-irrigated processing tomatoes. Acta Hort. 542:111-116

Dumas, Y., C. Leoni, C.A.M. Portas, and B. Bièche. 1994. Influence of water and nitrogen availability on yield and quality of processing tomato in the European union countries. Acta Hort. 376:185-192.

Ehret, D.L. and L.C. Ho. 1986. The effects of salinity on dry matter partitioning and fruit growth in tomatoes grown in nutrient film culture. $\mathrm{J}$. Hort. Sci. 61:361-367.

Goldhamer, D.A. and R.L. Snyder. 1989. Irrigation scheduling: A guide for efficient on-farm water management. Univ. Calif. Coop. Ext. Bul. 21454.

Hartz, T.K. 1996. Water management in drip-irrigated vegetable production. HortTechnology $6(3): 165-167$.
Hartz, T.K. 2001. Status of drip irrigation for processing tomato production in California. Acta Hort. 542:101-102.

Hartz, T.K. and G.J. Hochmuth. 1996. Fertility management of drip-irrigated vegetable. HortTechnology 6(3):168-172.

Hartz, T.K. and G. Miyao. 1997. Processing tomato production in California. Univ. Calif., Oakland, Div. Agr. Nat. Resour. Publ. 7228.

Linden, T. 2004. The brix discussion. Calif. Tomato Grower 47(2):5-8.

Lowengart-Aycicegi, A., H. Manor, R. Krieger, and G. Gera. 1999. Effects of irrigation scheduling on drip-irrigated processing tomatoes. Acta Hort. 487:513-518.

May, D.M. and J. Gonzales. 1999. Major California processing tomato cultivars respond differently in yield and fruit quality to various levels of moisture stress. Acta Hort. 487:525-529.

Phene, C.J., J.M. Miyamoto, K.R. Davis, R.L. McCormick, and R.C. Liu. 1986. Automated feedback irrigation scheduling and control with a weighing lysimeter. Proc. Agri-Mation 2:135-147.

Renquist, A.R. and J.B. Reid. 2001. Processing tomato fruit quality: Influence of soil water deficits at flowering and ripening. Austral. J. Agr. Res. 52:793-799.

Sakamoto, Y., S. Watanabe, T. Nakashima, and K. Okano. 1999. Effects of salinity at two ripening stages on the fruit quality of single-truss tomato grown in hydroponics. J. Hort. Sci. Biotechnol. 74:690-693.

Shock, C.C., J. Barnum, and M. Seddigh. 1998. Calibration of Watermark soil moisture sensors for irrigation management. Proc. Intl. Irr. Show 19:139-146.

U.S. Dept. of Agriculture. 1991. U.S. standards for grades of fresh tomatoes. USDA Agr. Mktg. Serv., Wash., D.C. 